\title{
Ostavština Hamdije Kapidžića u fondovima Specijalnih zbirki Nacionalne i univerzitetske biblioteke Bosne i Hercegovine
}

\author{
Heritage of Hamdija Kapidžić in the Funds of Special Collections of the National and \\ University Library of Bosnia and Herzegovina
}

Ismet Ovčina ${ }^{1}$, Muamera Smajić ${ }^{2}$, Alma Mešić ${ }^{3}$

Nacionalna i univerzitetska biblioteka Bosne i Hercegovine, Sarajevo, Bosna i Hercegovina / National and University Library of Bosnia and Herzegovina, Sarajevo, Bosnia and Herzegovina

${ }^{1}$ ismet@nub.ba, ${ }^{2}$ muameras@nub.ba, ${ }^{3}$ alma.mesic@nub.ba

\section{Informacije o članku / Article Info}

Primljen / Received 1. 6. 2020.

Prihvaćen / Accepted 9. 9. 2020.

Dostupan online / Available online: 15. 12. 2020.

Ključne riječi / Keywords:

Hamdija Kapidžić, Nacionalna i univerzitetska biblioteka BiH, Specijalne zbirke, pokloni, arhivi Hamdija Kapidžić, National and University Library of Bosnia and Herzegovina, Special Collections, gifts, archives

\begin{abstract}
Sažetak / Abstract
Korisnici Nacionalne i univerzitetske biblioteke Bosne i Hercegovine u svrhu različitih istraživanja često traže građu koja sadrži podatke o nacionalnoj i lokalnoj historiji, politici, kulturi. Nacionalna i univerzitetska biblioteka Bosne i Hercegovine svoje fondove, pored obaveznog primjerka, popunjava razmjenom i poklonima. Jedan takav poklon jeste i zaostavština historičara Hamdije Kapidžića. Biblioteka je ovaj poklon zaprimila 2008. godine. Dio poklona, koji čine nekoliko predmeta, korespondencija, pisma, razglednice, stare knjige, karte, nalazi se na Odjeljenju Specijalnih zbirki. Građa već duže vrijeme stoji neobrađena pa smo odlučili kroz ovaj kratki pregled i popis javnosti predočiti arhivu ovog znamenitog bosanskohercegovačkog kulturnog i naučnog radnika. Nadamo se da će ovaj kratak osvrt na zaostavštinu historičara Hamdije Kapidžića donijeti nove poglede na njegov život i znanstveni rad i poslužiti kao izvor za nova istraživanja.
\end{abstract}

Users of the National and University Library of Bosnia and Herzegovina, for the purpose of various researches, often look for material that contains national, local heritage, history, material about politics and culture. In addition to the obligatory copy, NUBBIH replenishes its funds with exchanges and gifts. One such gift is the legacy of historian Prof. Dr. Hamdija Kapidžić. The Library got this gift in 2008. Part of this gift - correspondence, letters, postcards, old books, maps, etc., are located in the Department of Special Collections. The material has been undocumented for a long time and we decided to present to the public the archives of this famous Bosnian cultural and scientific worker through this brief overview and list. We hope that this brief review of the legacy of the historian Hamdija Kapidžić will bring new views on his life and scientific work and serve as a source for new research.

\section{Prof. dr. Hamdija Kapidžić - život i djelo}

Prof. dr. Hamdija Kapidžić, ${ }^{1}$ naučnik, istraživač, član Akademije nauka i umjetnosti Bosne i Hercegovine, historičar, redaktor velikog opusa zbirki historijski značajne arhivske građe, rođen je u Bileći 1. 2. 1904. godine, ${ }^{2}$ gdje završava osnovnu školu, a

\footnotetext{
Dr. Enver Redžić u publikaciji "Hamdija Kapidžić - naučnik i pedagog" navodi kako je 1928. godine Kapidžić, na prijedlog Vasilja Popovića, u svom prezimenu sufiks "-čić" zamijenio u "-džić", pa se od tog perioda zove Kapidžić.

2 U svom članku "Prof. dr. Hamdija Kapidžić - znanstvenik i profesor", dr. Vera Katz napominje kako se u dostupnoj literaturi kao datumi rođenja dr. Kapidžića navode i 31. 1. te 2. 2. 1904. godine, dok dr. Enver Redžić ističe kako je Kapidžić rođen 1. 2. 1904. godine. Nacionalna univerzitetska biblioteka Bosne i Hercegovine u svom fondu posjeduje originalni Izvod iz rođenja (Auszug aus der Geburts), izdat 6. marta 1916. godine, u kojem se navodi da je prof. dr. Hamdija Kapidžić (Kapičić) rođen 1. 2. 1904. godine, od oca Ibre i majke Hanife, rođene Hajdarhodžić. Istovremeno, navedeni akt ukazuje na to da je izvorno prezime dr. Hamdije Kapidžića zapravo Kapičić.
}

\section{Hamdija Kapidžić - life and work}

Prof. Dr. Hamdija Kapidžić, ${ }^{1}$ scientist, researcher, member of The Academy of Sciences and Arts of Bosnia and Herzegovina, historian, editor of a large collection of historically significant archival material, was born in Bileća, on February $1^{\text {st }}$ in $1904,{ }^{2}$

\footnotetext{
In his publication "Hamdija Kapidžić: naučnik i pedagog", Dr. Enver Redžić states that in 1928, at the suggestion of Vasilj Popović, Kapidžić changed the suffix "-čić" to "-džić" in his surname, so from that period he was called Kapidžić.

In the article "Prof. Dr. Hamdija Kapidžić - scientific and professor", Dr. Vera Katz notes that in the available literature as dates of birth of Dr. Kapidžić are listed and January $31^{\text {th }}$ and February $2^{\text {nd }}$, 1904, while Dr. Enver Redžić points out that Kapidžić was born on February $1^{\text {st }}, 1904$. The National and University Library of Bosnia and Herzegovina has, in its funds, an original birth certificate (Auszug aus der Geburts), issued on March 6 $\mathrm{t}^{\mathrm{h}}, 1916$, in which it is stated that prof. Dr. Hamdija Kapidžić (Kapičić) was born on February $1^{\text {st }}$ 1904. His father was Ibro and mother Hanifa, born Hajdarhodžić. At the same time, a mentioned act indicates that the original surname of Dr. Hamdija Kapidžić is actually Kapičić.
} 
zatim gimnaziju u Mostaru. Studij historije pohađa na Filozofskom fakultetu u Beogradu te diplomira 1928. godine. U periodu od 1928. do 1942. godine radi kao profesor u Šerijatskoj gimnaziji u Sarajevu, od 1942. do 1948. godine u Drugoj muškoj gimnaziji, u kojoj je tri godine bio i direktor. Prof. dr. Hamdija Kapidžić svoje profesionalno djelovanje nastavlja prvo kao inspektor Ministarstva prosvjete Narodne republike Bosne i Hercegovine, zatim kao profesor na Višoj pedagoškoj školi, da bi 1952. godine na Filozofskom fakultetu u Sarajevu postao docent na predmetu Istorija naroda Jugoslavije novi vijek.

Prekretnica akademskog i naučnog djelovanja prof. dr. Kapidžića bila je izrada i odbrana doktorske disertacije na Filozofskom fakultetu u Beogradu 1956. godine, "kod profesora Vase Čubrilovića na temu Hercegovački ustanak 1882. godine" (Katz 2016, 226). Ova disertacija, koja je nastala kao produkt preciznog i dugogodišnjeg istraživanja arhivske građe u Bosni i Hercegovini i regionu, 1958. godine objavljena je kao monografija, "za koju je autor dobio Dvadesetsedmojulsku nagradu, kao najviše priznanje koje je tada Republika Bosna i Hercegovina dodjeljivala istaknutim stvaraocima" (Katz 2016, 227), a sama je monografija postala temelj budućih istraživanja historije Hercegovine u 19. stoljeću.

Prof. dr. Hamdija Kapidžić bio je vrlo plodonosan naučni radnik; prvobitne naučne radove počeo je objavljivati još 1930. godine, "sa kraćim prilozima iz istorije BiH 18. i 19. vijeka" (Redžić 2003, 7), potom je fokus djelovanja usmjerio k politici, ekonomiji, vojnoj, diplomatskoj, socijalnoj, kulturnoj problematici vladavine Austro-Ugarske monarhije u BiH. "U svojim radovima portretirao je oko dvadesetak ličnosti iz oblasti historiografije, a njegov moderan pristup znanosti ogleda se i u izučavanju starih gradova i tvrđava, načina života različitih socijalnih slojeva u njima." (Katz 2016, 228).

Iz ovakvog vrlo svestranog, detaljnog naučnog pera proizašao je veliki broj članaka, prikaza koji su produkt temeljitih istraživanja pa je 1968. godine objavljena monografija Bosna i Hercegovina $u$ vrijeme austrougarske vladavine (članci $i$ rasprave), koja je sakupila i objedinila sve radove nastale u proteklom periodu (Radušić 2018, 50). Prof. dr. Hamdija Kapidžić 1969. godine postaje dopisni član Akademije nauka i umjetnosti Bosne i Hercegovine, voditelj "Potkomisije za izradu istorije Bosne i Hercegovine za dionice austrougarske uprave u BiH” (Katz 2016, 226), jedan je od osnivača where he finished elementary school and then high school in Mostar. He studied history at the Faculty of Philosophy in Belgrade, graduated in 1928. In the period from 1928 to 1942, Prof. Dr. Kapidžić worked as a professor at the Sharia Gymnasium in Sarajevo, from 1942 to 1948 at the Second Men's Gymnasium, where he was a director for three years. Prof. Dr. Hamdija Kapidžić continued his professional career first as an inspector of the Ministry of Education of the People's Republic of Bosnia and Herzegovina, then as a professor at the Higher Pedagogical School, and in 1952 at the Faculty of Philosophy in Sarajevo he became an assistant professor of History of the Peoples of Yugoslavia - New Age.

A turning point in the academic and scientific work of Prof. Dr. Kapidžić was preparation and defense of doctoral dissertations at the Faculty of Philosophy in Belgrade in 1956, "mentored by professor Vaso Čubrilović on the topic of the Herzegovinian uprising in 1882" (Katz 2016, 226). This dissertation, created as a product of precise and long-term research of archival material in Bosnia and Herzegovina and the region, was published in 1958 as a monograph, "for which the author received the July 27 Award, as the highest recognition given by the Republic of Bosnia and Herzegovina to prominent creators" (Katz 2016, 227), and the monograph itself became the basis for future research of the history of Herzegovina in the $19^{\text {th }}$ century.

Prof. Dr. Hamdija Kapidžić was a very prolific researcher; he started publishing his original scientific works in 1930, "with form - short contributions to the history of BIH in the 18th and 19th centuries" (Redžić 2003, 7), then he focused on politics, economics, military, diplomatic, social, cultural issues of the rule of the Austro-Hungarian monarchy in BIH. "In his works, he portrayed about twenty figures, in the field of historiography, and his modern approach to science is reflected in the study of ancient cities and fortresses, the way of life of different social strata in them." (Katz 2016, 228).

From this very versatile, detailed scientific pen came a large number of articles, reviews that are the product of basic research, so a monograph Bosnia and Herzegovina during the Austro-Hungarian rule (members and debates) was published in 1968. It contains and consolidates all [Kapidžić's] works created in the past period. (Radušić 2018, 50).

In 1969, prof. dr. Hamdija Kapidžić became a corresponding member of The Academy of Sciences and Arts of Bosnia and Herzegovina, Head of the "Subcommittee on the History of Bosnia and Her- 
Društva istoričara Bosne i Hercegovine, osnivač i stalni saradnik časopisa Glasnik Arhiva i Društva arhivskih radnika Bosne i Hercegovine, svojevremeno je predsjedavao Arhivskim savjetom SR BiH, a svoje djelovanje i naučni doprinos dao je pri izgradnji Instituta za istoriju radničkog pokreta, odnosno Instituta za istoriju u Sarajevu.

Ovaj dobitnik velikog broja priznanja, profesor svjetskog naučnog kalibra, vrlo plodonosnog naučnoistraživačkog opusa, ${ }^{3}$ društveno angažiran humanista, intelektualac, umro je u Sarajevu 16. 1. 1974. godine.

\section{Popis građa iz ostavštine Hamdije Kapidžića}

Na Odjeljenju Specijalnih zbirki NUBBiH nalazi se građa iz privatne kolekcije Hamdije Kapidžića koja sadrži nekoliko predmeta, korespondenciju, pisma, razglednice, stare knjige, karte itd. Biblioteka je ovaj poklon zaprimila 2008. godine. S obzirom na to da građa već duže vrijeme stoji nedokumentirana, odlučili smo u kratkim crtama predočiti javnosti arhivu ovog znamenitog bosanskohercegovačkog kulturnog i naučnog radnika. U nastavku vam donosimo kratki popis ove građe.

\section{Fascikla 1}

1. SKARIĆ, Vladislav. Popis bosanskih spahija iz 1123. (1711.) god : sa 1 tablom, 4 karte i 2 slike u tekstu. - Sarajevo : Državna štamparija, 1930. *Na nasl. str.: Primarnom lekaru i gospodinu Hamdiji Karamehmedoviću iz poštovanja pisac.

2. MUSIĆ, August. Gramatika grčkog jezika. Zagreb : St. Kugli, 1926.

*Na prelim. str.: potpis Muhameda Kreševljakovića. Na nasl. str.: potpis Fadile Kapidžić.

3. KAPOR, Ambroz. Prerada duvana u Bosni i Hercegovini : od prvih početaka do 1923. godine. - Sarajevo : Naklada Fabrike duvana Sarajevo, 1954.

\section{Fascikla 2}

1. KREŠEVLJAKOVIĆ, Hamdija. Esnafi i obrti u Bosni i Hercegovini. [Dio] 2. Mostar. - Zagreb : Jugoslovenska akademija znanosti i umjetnosti, 1951.

P. o.: Zbornik za narodni život i običaje Južnih Slavena ; knj. 35, 1951.

*Na prelim. str. posveta autora: Prijatelju $d r$. Hamdiji Karamehmedoviću na uspomenu, pisac. 14. 10. 1957.

\footnotetext{
Katz (2016) ukazuje kako taj broj uključuje preko 130 bibliografskih jedinica.
}

zegovina for the shares of the Austro-Hungarian administration in B\&H" (Katz 2016, 226), also he was one of the founders of the Society of Historians of Bosnia and Herzegovina, a founder and permanent contributor to the journal Gazette of the Archive and the Association of Archival Workers of Bosnia and Herzegovina, was head of The Archives Council of Socialistic Republic BIH. Also, Kapidžić gave scientific contributions to the construction of the Institute for the History of the Workers' Movement, i.e. the Institute for History in Sarajevo.

This winner of a large number of awards, a professor of world scientific caliber, a very fruitful scientific research opus, ${ }^{3}$ a socially engaged humanist, an intellectual, died in Sarajevo on January $16^{\text {th }}, 1974$.

\section{List of materials from the legacy of H. Kapidžić}

Part of the gift of Hamdija Kapidžić's private collection, which contains several objects, correspondence, letters, postcards, old books, maps, etc., was delivered to the Department of Special Collections of NUBBIH in 2008. The library received this gift in 2008. Considering that the material has been undocumented for a long time, we decided to present to the public the archive of this famous Bosnian cultural and scientific worker. Below is a shortlist of this material.

\section{Folder 1}

1. SKARIĆ, Vladislav. Popis bosanskih spahija iz 1123. (1711.) god : sa 1 tablom, 4 karte i 2 slike u tekstu. - Sarajevo : Državna štamparija, 1930.

*On the front page: To the primary doctor and Mr. Hamdija Karamehmedović, respectfully, writer.

2. MUSIĆ, August. Gramatika grčkog jezika. Zagreb : St. Kugli, 1926.

*Signature of Muhamed Kreševljaković on the prelims page of publication. On the front-page signature by Fadila Kapidžić.

3. KAPOR, Ambroz. Prerada duvana u Bosni i Hercegovini : od prvih početaka do 1923. godine. - Sarajevo : Naklada Fabrike duvana Sarajevo, 1954.

\section{Folder 2}

1. KREŠEVLJAKOVIĆ, Hamdija. Esnafi i obrti u Bosni i Hercegovini. [Dio] 2. Mostar. - Zagreb : Jugoslovenska akademija znanosti i umjetnosti, 1951.

Katz (2016) indicates that this number includes over 130 bibliographic items. 
2. KAPIDŽIĆ, Hamdija. Stolac u XVIII vijeku. Sarajevo : Bosanska Pošta, 1940. 19 str. [COBISS.BH-ID 128567052]

3. HANDŽIĆ, Mehmed. Islamizacija Bosne i Hercegovine i porijeklo bosansko-hercegovačkih muslimana. - Sarajevo : Islamska dionička štamparija, 1940.

*Na vrhu nasl. str. bilješka : Datum 2. 3. 1940. i potpis Kapidžić

4. MARDEŠIĆ, Petar. Kako se čita karta. - Zagreb : Seljačka sloga, 1950.

5. PLANINARSKE kuće i domovi u Bosni i Hercegovini. - Sarajevo: Sarajevsko planinarsko društvo „Bjelašnica“, 1955.

6. BENAC, Alojz. Sarajevo : od najstarijih vremena do danas. - Sarajevo : Muzej grada, 1954. *Na nasl str. : Posveta autora Hamdiji Kapidžiću, 10. 09. 1954.

7. MANDIĆ, Mihovil. Vezirski grad Travnik : nekada i sada. Zagreb : Matica hrvatska, 1931.

\section{Fascikla 3}

SARAJEVO : Congressus Archeologorum 18944 : Ilidže, - Sobunar, - Butmir, - Glasinac, - [17 tabli sa fotografijama].

Fotografije se nalaze u kutiji, numerisane rukom u sljedećem redoslijedu:

1. Butmir (Ilidže), 16. 8. 1984. - Tri fotografije na tabli. Fotografije sa prikazom lokacije iskopavanja.

2. Rusanović (Glasinac), 16. 8. 1894. - Veća grupa ljudi na iskopinama.

3. Rusanović (Glasinac), 20. 8. 1894. - Tabla sa dvije fotografije, mještani u narodnim nošnjama.

\footnotetext{
“15. augusta 1894. godine, u Bosni i Hercegovini, u Sarajevu počeo je Međunarodni kongres arheologa i antropologa. U našoj zemlji to je bilo vrijeme izuzetnih otkrića: neolitska stanica u Butmiru, tumuli na Glasincu, sojenice u Ripču i Donjoj Dolini, japodske nekropole u dolini Une i dr. Ova nalazišta postala su temelj prahistorijskoj arheologiji u Bosni i Hercegovini, a ogromna količina prikupljenog i obrađenog materijala postaje osnova fonda prahistorijske zbirke Zemaljskog muzeja BiH.

Ovako značajni rezultati postignuti u relativno kratkom vremenskom roku odjeknuli su u evropskoj kulturnoj i naučnoj javnosti. Putem Glasnika Zemaljskog muzeja $\mathrm{BiH}$ i Wissenschafliche Mittheilungen aus Bosnien und der Hercegovina, europski i svjetski naučnici imali su priliku da se upoznaju sa radom stručnjaka Zemaljskog muzeja $\mathrm{BiH}$. Zemaljska vlada, kako bi ova značajna otkrića na polju prahistorijske arheologije i antropologije podijelila sa što većim brojem ljudi, organizira Međunarodni kongres arheologa i antropologa u Sarajevu od 15. - 21. augusta 1894. godine.

Ovom skupu prisustvovali su stručnjaci arheolozi i antropolozi iz Engleske, Francuske, Italije, Švedske, Švicarske, Njemačke i Austro-Ugarske. Prisustvo naučnika iz cijele Europe, kao i pozitivne ocjene za rezultate istraživanja značilo je i definitivan ulazak Bosne i Hercegovine u krug europske nauke i kulture." (Zemaljski muzej Bosne i Hercegovine 2017)
}

P. o.: Zbornik za narodni život i običaje Južnih Slavena; knj. 35, 1951.

*On the prelim. $p$. dedication of the author: To a friend, dr. Hamdija Karamehmedović in memory, writer. October $14^{\text {th }}, 1957$.

2. KAPIDŽIĆ, Hamdija. Stolac u XVIII vijeku. Sarajevo : Bosanska Pošta, 1940. 19 str. [COBISS.BH-ID 128567052]

3. HANDŽIĆ, Mehmed. Islamizacija Bosne i Hercegovine i porijeklo bosansko-hercegovačkih muslimana. - Sarajevo : Islamska dionička štamparija, 1940.

*At the top of the title page: Date 2 March 1940 and signature Kapidžić.

4. MARDEŠIĆ, Petar. Kako se čita karta. - Zagreb : Seljačka sloga, 1950.

5. PLANINARSKE kuće i domovi u Bosni i Hercegovini. - Sarajevo: Sarajevsko planinarsko društvo "Bjelašnica", 1955.

6. BENAC, Alojz. Sarajevo : od najstarijih vremena do danas. - Sarajevo : Muzej grada, 1954. *On the title page: Author's dedication to Hamdija Kapidžić, September 10, 1954.

7. MANDIĆ, Mihovil. Vezirski grad Travnik : nekada i sada. Zagreb : Matica hrvatska, 1931.

\section{Folder 3}

SARAJEVO : Congressus Archeologorum 18944. Ilidže, - Sobunar, - Butmir, - Glasinac, - [17 boards with photographs].

The photos are in the box, numbered by hand in the following order:

1. Butmir (Ilidže), August 16 $6^{\text {th }}, 1894$. - Three photos on the board. Photos showing the location of the excavation.

\footnotetext{
"The International Congress of Archaeologists and Anthropologists began in Sarajevo on the $15^{\text {th }}$ of August 1894. In our country, it was a time of extraordinary discoveries: Neolithic station in Butmir, tumuli on Glasinac, pile dwelling in Ripče and Donja Dolina, Iapodian necropolises in the Una valley, etc. These sites became the basis of prehistoric archeology in Bosnia and Herzegovina, and a huge amount of collected and processed materials become the basis of the fund of the prehistoric collection of the National Museum of BIH. Such significant results achieved in a relatively short period of time resonated with the European cultural and scientific public. Through the Gazette of the National Museum of BIH and the Wissenschafliche Mittheilungen aus Bosnien und der Herzegovina, European and world scientists had the opportunity to get acquainted with the work of experts from the National Museum of BIH. The Provincial Government, in order to share these significant discoveries in the field of prehistoric archeology and anthropology with as many people as possible, organized the International Congress of Archaeologists and Anthropologists in Sarajevo from August $15^{\text {th }}$ to $21^{\text {th }}$, in 1894 . This gathering was attended by expert archaeologists and anthropologists from England, France, Italy, Sweden, Switzerland, Germany, and Austro-Hungary. The presence of scientists from all over Europe, as well as positive evaluations of the research results, meant the definitive entry of Bosnia and Herzegovina into the circle of European science and culture." (Zemaljski muzej Bosne i Hercegovine 2017)
} 
4. Podromanja, Rusanović, 19.-20. 8. 1984. Tabla sa tri fotografije, na svakoj veća grupa ljudi na proplanku, smotra.

5. Rusanović (Glasinac), 20. 8. 1894. - Grupa ljudi koja prisustvuje iskopavanju na lokalitetu Rusanovići.

6. Butmir (Ilidže), 16. 8. 1894. - Na fotografiji je prikazan proces iskopavanja na Butmiru

7. Megara - Crkvina (Glasinac), 19. 8. 1894. Na tabli se nalaze tri fotografije. Na prvoj se vidi ulaz u pećinu (Megara), dok su na druge dvije grupa ljudi kod nekropole sa stećcima.

8. Hreljingrad (Glasinac), 19. 8. 1894. - Manja grupa konjanika na proplanku.

9. Rusanović (Glasinac), 20. 8. 1894. - Tri djevojke u narodnoj nošnji.

10. Butmir (Ilidže), 16. 8. 1894. - Na fotografiji je prikazan proces iskopavanja na Butmiru.

11. Rusanović (Glasinac), 20. 8. 1894. - Veća grupa ljudi koja prisustvuje iskopavanju na lokalitetu Rusanovići.

12. Butmir (Ilidže), 16. 8. 1894. - Na fotografiji je prikazan proces iskopavanja na Butmiru.

13. Butmir (Ilidže), 16. 8. 1894. - Na fotografiji je prikazan proces iskopavanja na Butmiru.

14. Hreljingrad (Glasinac), 19. 8. 1894. - Velika grupa konjanika na proplanku.

15. Rusanović (Glasinac), 20. 8. 1894. - Fotografija prikazuje tri osobe u narodnoj nošnji.

16. Mokro, 19. 8. 1894. - Na tabli se nalaze dvije fotografije. Na prvoj je prikazana seoska kuća sa okućnicom, a na drugoj se nalazi čovjek u narodnoj nošnji koji sjedi ispred radnje i svira saz.

17. Butmir (Ilidže), 16. 8. 1894. - Na fotografiji je prikazan proces iskopavanja na Butmiru.

*Na poleđini poklopca kartonske kutije u kojoj se nalaze fotografije: Poklon od Preuzvišenog gospodina barona Hugo Kutchera Mustafi Kalabi, Sarajevo, 1. maj 1904. 14 komada slika Ilidže Butmir Glasinac Njegova preuzvišenost ministar Burian $i$ baron Kutcher odputovali su u zajednici iz Sarajeva u Beč u utorak 3. maja 1904.

Fascikla 4 - razglednice, čestitke, dopisnice, pozivnice

- 82 razglednice, čestitke, dopisnice, pozivnice, pisma upućeni uglavnom Hamdiji Kapidžiću, a nekoliko naslovljeno i Nedžibu Kapidžiću, Mejri Kapidžić i Dili Kapidžić. Upućene su iz gradova Bosne i
2. Rusanović (Glasinac), August $16^{\text {th }}, 1894 .-A$ larger group of people at the excavations.

3. Rusanović (Glasinac), August 20 $0^{\text {th }}, 1894$ Board with two photos, locals in folk costumes.

4. Podromanja, Rusanović, August $19-20^{\text {th }}$, 1894. - A board with three photos, in each larger group of people in the clearing, looks.

5. Rusanović (Glasinac), August $20^{\text {th }}, 1894$. - A group of people attending the excavation at the Rusanovici site.

6. Butmir (Ilidže), August $16^{\text {th }}, 1894$. - The photo shows the excavation process on Butmir.

7. Megara - Crkvina (Glasinac), August $19^{\text {th }}$, 1894. - There are three photos on the board. The first one shows the entrance to the cave (Megara), while the other two groups of people near the necropolis of tombstones.

8. Hreljingrad (Glasinac), August 19 $9^{\text {th }}, 1894$. - A small group of horsemen in the clearing.

9. Rusanović (Glasinac), August 19 ${ }^{\text {th }}, 1894$. Three girls in traditional costumes.

10. Butmir (Ilidže), August $16^{\text {th }}, 1894$. - The photo shows the excavation process on Butmir.

11. Rusanović (Glasinac), August $20^{\text {th }}, 1894$. - A larger group of people attending the excavation at the Rusanovići site.

12. Butmir (Ilidže), August $16^{\text {th }}, 1894$. - The photo shows the excavation process at Butmir.

13. Butmir (Ilidže), August $16^{\text {th }}$, 1894. - The photo shows the excavation process at Butmir.

14. Hreljingrad (Glasinac), August 19 ${ }^{\text {th }}$, 1894. - A large group of horsemen in the clearing.

15. Rusanović (Glasinac), August 20 ${ }^{\text {th }}, 1894$. The photo shows three people in traditional costumes.

16. Mokro, August 19 $19^{\text {th }} 1894$. - There are two photos on the board. The first shows a village house with a garden, and the second shows a man in traditional costume sitting in front of the shop and playing saz.

17. Butmir (Ilidže), August $16^{\text {th }} 1894$. - The photo shows the excavation process on Butmir. *On the back of the lid is a cardboard box: Gift from His Eminence Baron Hugo Kutcher to Mustafa Kalaba, Sarajevo, May $1^{\text {st }}$, 1904. 14 pieces of paintings of Ilidža Butmir Glasinac His Excellency Minister Burian and Baron Kutcher traveled in a community from Sarajevo to Vienna. Tuesday, May $3^{\text {rd }}, 1904$. 
Hercegovine, bivše Jugoslavije (Slovenije, Srbije, Hrvatske, Kosova), te Austrije, Turske, Slovačke, Francuske, Njemačke i Rusije.

Fascikla 5 - privatne i porodične fotografije

- 17 fotografija na kojima se nalaze sin Nedžib i snaha Nada

- 4 fotografije na kojima je kćerka Fadila

- 3 fotografije na kojima je punac Salih

- 3 fotografije na kojima je Hamdija Kapidžić

\section{Fascikla 6}

1. Dvije (2) geografske karte:

- FEDERATIVNA Narodna Republika Jugoslavija [Kartografsko gradivo] / priredili V. [Valter] Bohinec i Fr. [France] Planina ; izradio Ivan Selan. - 1:1.500.000. - Ljubljana : Državna založba Slovenije, 1960.

- [BOSANSKO-hercegovački ustanak 18751877] [Kartografsko gradivo]. 1:1.000.000.

2. SARAJEVO 3 [Kartografsko gradivo] 1:50.000. - [Sarajevo] : Geografski Institut JNA, [197-].

[COBISS.BH-ID 16682758]

3. BJELAŠNICA s okolicom. - 1:50.000. - Sarajevo : Planinarsko društvo Bjelašnica, [196-]. [COBISS.BH-ID 14664460]

4. Rodni list Hamdije Kapidžića [Izvod iz knjige rođenih za 1904. godinu] - Auszug aus der (Geburts-), matrikel über die im Jahre 1904 geborenen Knaben.

*Rodni list je izdat 06. marta 1916. godine u Bileći

5. Jedna tabla sa fotografijom [Jakub bega Filipovića]

6. Odluka o nasljedstvu Zemljišno knjižnog ureda Sreskog suda u Bileći od 17. 11. 1956. godine. - 2 str.

*Raspodjela imovine Ahmeta Kapičića.

\section{Fascikla 7}

- 6 sveski sa bilješkama koje je Hamdija Kapidžić prikupio tokom istraživanja u periodu od 1960. do 1966. godine. Bilješke su na bosanskom i njemačkom jeziku.

\section{Fascikla 8}

- 81 pismo upućeno uglavnom Hamdiji Kapidžiću, te Mejri Smailbegović, Salihi Smailbegović, Ahmedu Bijediću, Hanifi Kapidžić i Fadili Kapidžić. Pisma su upućena većinom iz gradova Bosne i Hercegovine i nekoliko iz Srbije, Hrvatske i Austrije.
Folder 4 - postcards, greeting cards, invitations

- 82 pieces of postcards, greeting cards, invitations, letters sent mainly to Hamdija Kapidžić, and several addressed to Nedžib Kapidžić, Mejra Kapidžić, and Dila Kapidžić. They were sent from the cities of Bosnia and Herzegovina, the former Yugoslavia (Slovenia, Serbia, Croatia, Kosovo), Austria, Turkey, Slovakia, France, Germany, and Russia.

Folder $\mathbf{5}$ - private and family photos

- 17 photos of son Nedžib and daughter-in-law Nada.

- 4 photos of daughter Fadila.

- 3 photos showing Salih's father-in-law.

- 3 photos of Hamdija Kapidžić.

\section{Folder 6}

1. Two (2) geographical maps:

- FEDERATIVNA Narodna Republika Jugoslavija [Kartografsko gradivo] / priredili V. [Valter] Bohinec i Fr. [France] Planina ; izradio Ivan Selan. - 1:1.500.000. - Ljubljana : Državna založba Slovenije, 1960.

- [BOSANSKO-hercegovački ustanak 18751877]. 1:1.000.000

2. SARAJEVO 3 - 1:50.000. - [Sarajevo] : Geografski Institut JNA, [197-].

[COBISS.BH-ID 16682758]

3. BJELAŠNICA s okolicom. - 1:50.000. - Sarajevo : Planinarsko društvo "Bjelašnica", [196-]. [COBISS.BH-ID 14664460]

4. Birth certificate for Hamdija Kapidžić [Birth cerfiticate for 1904] - Auszug aus der (Geburts-), matrikel über die im Jahre 1904 geborenen Knaben.

*The birth certificate was issued on March $6^{\text {th }}$, 1916 in Bileća.

5. One board with a photo [of Jakub bey Filipović].

6. Resolution on the inheritance of the Land Registry Office of the District Court in Bileća of 17 November 1956. - 2 pages.

*Distribution of Ahmet Kapičić's property.

\section{Folder 7}

- 6 notebooks with notes collected by Hamdija Kapidžić during the research in the period from 1960 to 1966. Notes are written in Bosnian and German language.

\section{Folder 8}

- 81 letters sent mainly to Hamdija Kapidžić, and Mejra Smailbegović, Saliha Smailbegović, 


\section{Fascikla 9-Rukopisi:}

1. Popis građe iz Bečkog arhiva koji sadrži podatke o odnosima balkanskih država i Austro-Ugarske prije 1912. godine i o prilikama na Balkanu i Bosni i Hercegovini. - 6 listova kucanog teksta.

2. Prikaz knjige: Novi prilozi proučavanju veza između Vojvodine i Bosne i Hercegovine / K. Milutinović. - 5 listova kucanog teksta.

*Prikaz objavljen u: Zbornik Matice srpske. Serija društvenih nauka; sv. 6.

3. Rad Hamdije Kapidžića: Veze Dubrovnika, Bosne i Hercegovine u 18. vijeku : kraći prilozi istorije naše medicine. - 5 listova kucanog teksta.

4. Razne bilješke o historiji Balkana (Osmanski period). - 15 listova.

5. Bilješke o: Seljački ustanci u slovenačkim zemljama; Etnički položaj i teritorijalne promjene od kraja 15. do 17. vijeka. - 21 list.

6. Bilješke o: Slovensko-hrvatski seljački ustanak. - 10 listova.

7. Bilješke o: Popović Aleksa - sarajevska revolucija. -6 str.

8. Razne bilješke - 16 str.

9. 39 pisama i 13 dopisnica.

\section{Fascikla 10}

1. Pismo Hasan-bega Resulbegovića, zapovjednika trebinjskog, septembar 1842. godine [zapovjedniku okoliša Dubrovnika, Karlu baron(u) P?]

2. 7 pisama na italijanskom jeziku iz 1835. godine nepoznatog sadržaja; pisma su numerisana - 48, 58, 65, 80, 103.

3. Telegram na italijanskom jeziku, datiran 8. 8 . 1863. godine.

4. Pismo na italijanskom jeziku, datiran 24. maj 1842. godina.

5. Pismo na italijanskom, datiran 30. 9. 18??.

6. 2 lista teksta na italijanskom o Hercegovini.

7. Pismo iz 1862. godine od Miloševića iz Trebinja.

8. 2 dokumenta na tursko-osmanskom jeziku iz 1840. godine.

9. Glavni izvršni odbor "Gajreta", Sarajevo, 13. januar 1934. godine. Okružnica: svim mjesnim odborima i povjerenicima "Gajreta" - 3 lista kucanog teksta.

*Obrazloženje povodom istupa g. H. Brkića iz Glavnog odbora "Gajreta".
Ahmed Bijedić, Hanifa Kapidžić, and Fadila Kapidžić. These letters were sent mostly from the cities of Bosnia and Herzegovina and a few from Serbia, Croatia, and Austria.

\section{Folder 9 - manuscripts}

1. List of material from the Vienna Archives, which contains data on the relations between the Balkan states and Austria-Hungary before 1912 and on the situation in the Balkans and Bosnia and Herzegovina. - 6 sheets of typed text.

2. Book review: New contributions to the study of relations between Vojvodina and Bosnia and Herzegovina / K. Milutinović - 5 sheets of typed text.

*Review published in: Zbornik Matice srpske. Serija društvenih nauka; sv 6.

3. The work of Hamdija Kapidžić: Connections of Dubrovnik, Bosnia and Herzegovina in the 18th century: short contributions to the history of our medicine. - 5 sheets of typed text.

4. Various notes on the history of the Balkans (Ottoman period). - 15 sheets.

5. Notes on: Peasant uprisings in Slovenian lands; Ethnic position and territorial changes from the end of the 15th to the 17th century. - 21 sheets.

6. Notes on: Slovenian-Croatian peasant uprising. -10 sheets.

7. Notes on: Popović Aleksa - Sarajevo Revolution. - 6 pages.

8. Various notes -16 pages.

9. 39 letters and 13 stationery.

\section{Folder 10}

1. Letter from Hasan-bey Resulbegović, Commander of Trebinje, September 1842 [to the Commander of the Environment of Dubrovnik, Karl Baron P?].

2. 7 letters in Italian from 1835 of unknown content; the letters are numbered $-48,58,65,80$, 103.

3. Telegram in Italian, dated $8^{\text {th }}$ August 1863.

4. Letter in Italian, $24^{\text {th }}$ May 1842 (Herzegovina).

5. Letter in Italian, $30^{\text {th }}$ September $18 ? ?$.

6. 2 sheets of text in Italian about Herzegovina.

7. A letter from 1862 from Milošević from Trebinje.

8. 2 documents in Turkish-Ottoman language from 1840 . 


\section{Fascikla 11}

- Razni privatni dokumenti, računi, kopije pisama, smrtovnice (3 komada).

\section{U arhivu se u sklopu zaostavštine nalaze još i:}

- Kopije bh. karata i planova na staklenim pločama (6 kutija)

- 1 kutija (13 x $18 \mathrm{~cm})$ sa kopijama dokumenata iz Ratnog arhiva Beč (Kriegsarchiv)

- Lični pribor: olovka, držač za pero, nož za otvaranje pisma, novčanik, naočale.

\section{Publikacije Hamdije Kapidžića koje se nalaze u Nacionalnoj biblioteci Austrije}

Dr. Hamdija Kapidžić istraživao je i prikupljao građu u Austriji. Neke od njegovih publikacija nalaze se i u Nacionalnoj biblioteci Austrije, a to su:

1. KAPIDŽIĆ, Hamdija. Bosna i Hercegovina pod austrougarskom upravom : (članci i rasprave). - Sarajevo : Svjetlost, 1968.

2. DER Aufstand in der Hercegovina, Süd-Bosnien und Süd-Dalmatien 1881-1882 : mit 3 Karten / nach authentischen Quellen dargestelt in der Abtheilung für Kriegsgeschichet des k. k. Kriegs-Archivs. - Wien : K. k. Generalstabes, 1883.

3. KAPIDŽIĆ, Hamdija. Prilozi za istoriju Bosne i Hercegovine u XIX vijeku. - Sarajevo : Naučno društvo NR Bosne i Hercegovine, 1956.

4. AGRARNI odnosi u BiH : (1878-1918). I. Građa / redaktor Hamdija Kapidžić. - Sarajevo : Arhiv Bosne i Hercegovine, 1969.

5. KAPIDŽIĆ, Hamdija. Hercegovački ustanak 1882. godine. - Sarajevo : "Veselin Masleša", 1973.

6. NAUČNE ustanove u Bosni i Hercegovini za vrijeme Austrougarske uprave / sabrao i uredio Hamdija Kapidžić ; tehnički urednik Kasim Isović. - Sarajevo : Arhiv Bosne i Hercegovine, 1973.

7. KREŠEVLJAKOVIĆ, Hamdija; KAPIDŽIĆ, Hamdija. Vojno-geografski opis Bosne pred Dubički rat : od 1785. godine. - Sarajevo : Naučno društvo Bosne i Hercegovine, 1957.
9. Main Executive Board of Gajret, Sarajevo, January $13^{\text {th }}, 1934$. Circular: to all local committees and commissioners of "Gajret" - 3 sheets of typed text.

*Explanation on the withdrawal of Mr. H. Brkic from the Main Board of "Gajret".

\section{Folder 11}

1. Various private documents, invoices, copies of letters, obituaries ( 3 pieces)

\section{The archive also includes:}

- Copies of maps and plans of BIH on glass plates ( 6 boxes)

- 1 box $(13 \times 18 \mathrm{~cm})$ with copies of documents from the Vienna War Archives (Kriegsarchiv)

- Personal accessories: pen, pen holder, letter opener, wallet, glasses.

\section{Publications written by Hamdija Kapidžić which are located in The National Library of Austria}

Dr. Hamdija Kapidžić researched and collected material in Austria. Some of his publications are also in the National Library of Austria. We bring you a list of this material below as it is available in the catalog:

1. KAPIDŽIĆ, Hamdija. Bosna i Hercegovina pod austrougarskom upravom : (članci i rasprave). - Sarajevo : Svjetlost, 1968.

2. DER Aufstand in der Hercegovina, Süd-Bosnien und Süd-Dalmatien 1881-1882 : mit 3 Karten / nach authentischen Quellen dargestelt in der Abtheilung für Kriegsgeschichet des k. k. Kriegs-Archivs. - Wien : K. k. Generalstabes, 1883.

3. KAPIDŽIĆ, Hamdija. Prilozi za istoriju Bosne i Hercegovine u XIX vijeku. - Sarajevo : Naučno društvo NR Bosne i Hercegovine, 1956.

4. AGRARNI odnosi u BiH : (1878-1918). I. Građa / redaktor Hamdija Kapidžić. - Sarajevo : Arhiv Bosne i Hercegovine, 1969.

5. KAPIDŽIĆ, Hamdija. Hercegovački ustanak 1882. godine. - Sarajevo : "Veselin Masleša", 1973.

6. NAUČNE ustanove u Bosni i Hercegovini za vrijeme Austrougarske uprave / sabrao i uredio Hamdija Kapidžić ; tehnički urednik Kasim Isović. - Sarajevo : Arhiv Bosne i Hercegovine, 1973.

7. KREŠEVLJAKOVIĆ, Hamdija; KAPIDŽIĆ, Hamdija. Vojno-geografski opis Bosne pred Dubički rat : od 1785. godine. - Sarajevo : Naučno društvo Bosne i Hercegovine, 1957. 


\section{Literatura / Bibliography}

- Kamberović, Husnija. (ur.) 2004. Bosna i Hercegovina u uspomenama Leona Bilińskog. Sarajevo: Institut za istoriju.

- Katz, Vera. 2016. "Prof. dr. Hamdija Kapidžić znanstvenik i profesor", Rad predstavljen na $\mathrm{Na}$ učnom skupu Hercegovački naučnici/znanstvenici i tradicija istraživanja u Hercegovini, Mostar, decembar 2015.

- Radušić, Minela. 2018. Jugoslavensko ujedinjenje u djelu Hamdije Kapidžića: Bosna i Hercegovina $u$ vrijeme Austrougarske vladavine (članci $i$ rasprave): između povijesnih činjenica i ideološkog revizionizma. Sarajevo: Udruženje za modernu historiju.
- Redžić, Enver. 2003. Hamdija Kapidžić: naučnik i pedagog. Sarajevo, Akademija nauka i umjetnosti Bosne i Hercegovine.

- Zemaljski muzej Bosne i Hercegovine. 2017. "15. augusta 1894. godine, u Bosni i Hercegovini, u Sarajevu počeo je Međunarodni kongres arheologa i antroplologa" Facebook, 15 august 2017. https://www.facebook.com/zemaljskimuzej/posts/10156539857889196. 